\title{
Sustainable urban habitats: design intentions to practical implementation
}

Alan Keith Derbyshire

University of Central Lancashire, Lancashire, UK

The absence of a shared definition of the variable that is sustainability is a volatile element in the multi-factor equation known as 'the urban landscape'. The sustainable infrastructure of our urbanised habitats is a fundamental matter for planners and architects, but this is often more of a theoretical concern than a practical application of innovative design implementation. The lack of a shared understanding of sustainable practices contributes to a reliance on conventional orthodoxies, and the 'play it safe' approach to the design of public spaces structurally and aesthetically. This study focuses on the methodological and creative threads that connect sustainable design concepts to their viable outcomes. The recent phenomenon of significant population growth within UK regional city centres has emphasised the demand for user-friendly ecologically enhanced public spaces. The synthesis of native species ecology and innovative utilisation of hard landscaping is a fundamental element in the establishment of the concepts of ownership and place. The successful employment of these concepts is debatable. The strands that link worthy sustainable architectural and planning design intentions to their seemingly logical conclusions are frayed, tangled and often severed. Through a selection of comparative case studies and examples of advanced initiatives this paper examines the causes of this entanglement and paradoxically also highlights the innovative capacity of reversing the existing 'fixed mould of aesthetic convention'.

\section{Introduction}

Over the last decade within the UK there has been an exponential increase in city-centre living. Historically the centres of regional cities such as Manchester, Liverpool and Birmingham have been areas of commerce and industry. The notion of city-centre dwelling is now perceived as desirable and aspirational, an impression actively encouraged by developers. The rise in city-centre living has occurred against a backdrop of increasing awareness of ecological matters; global warming is now an established topic of concern and the sustainability of the environment has become a fashionable cause. With the increase in city-centre dwelling, the debate concerning sustainable urbanity is unavoidable and the reliance on 'tried and trusted' orthodoxies is more uncertain. Sustainability is hard to define and as a consequence this lack of a clear and agreed definition often leads to poor communication in the planning and development stage of urban landscaping. The inadequacies of the communication in the planning of developments are matched by the reluctance of designers to make bold choices in the choices of ecology and hard landscaping materials.

This paper reviews the current approaches of architects, designers and planners to the development of sustainable urban habitats, and identifies the limitations of current sustainable design practice. There are three identifiable barriers to the successful implementation of sustainable urban landscape design highlighted within the study

(a) the failure adequately to acknowledge a sense of place

(b) the disjunction between sustainable building design and landscape design

(c) conventional designs paying no more than lip service to ecological sustainability.

Concepts of place and sustainability are central to the debate. The fuzziness of the collective understanding of these critical concepts among design professionals is a basic issue. The uncertainty of practitioners when implementing sustainable solutions leads either to a rigid adherence to established formulae or token references to sustainable practices. This disparity often results in sustainable inconsistency, visually banal and ecologically inconsequential urban landscapes, often made more pronounced by the divergence with sustainable architecture.

The ecology of urbanity is a fundamental element in establishing bona fide sustainability. Hester (1995) asserts that 'we no longer experience ecological dependence or community connections in our daily lives as, say, a farmer does. Our disassociation from the world around us offers us enormous short term freedom, but with 
Urban Design and Planning

Volume 164 Issue DP1
Sustainable urban habitats:

design intentions to practical

implementation

Derbyshire adverse long-term consequences.' If we are unable to design appropriately, and respond to the ecology of the urban environment, the establishment of place is compromised, as is the viable sustainability of the development of urban spaces.

With this in mind the paper examines the creative potential of the use of ecology, natural processes and landscaping materials and considers the traditional application of modernist theories to sustainable landscape developments. The reliance on modernism as a benchmark of acceptable design has led to the clinging to the comfort blanket of conformity and as a result homogenised banality. Osmond (2002) argues that 'the overwhelming impression of the western (or westernised) urban exterior is of islands of corporate 'blandscape' in a sea of fragmented and car dominated leftover space'. The cultural complexities that influence the debate concerning modernism and a more fortuitous approach to the designed landscape are useful subjects for discussion. However, an urgent reappraisal of existing paradigms is necessary in order to begin to achieve authentic sustainable urbanity.

\section{Sustainability and place}

Notions of sustainability and place are connected by the shared complication of how to define their fundamental meaning adequately. The creative application of both concepts is critical to the establishment of genuine sustainable design objectives. If developments lack the potential for dwelling and a sense of ownership they are essentially unsustainable.

Emotional responses to the landscape are complex, but in order to create a broader dialogue and connect with the public sustainable urban habitats need to connect visually and emotionally (Motloch, 2001). The creation of 'placeness' is an integral element of built environment design processes when attempting to re-negotiate the character of sites. Places are perceived to include psychological, social and human activities rooted within a physical setting (Brandenburgh and Carroll, 1995; Relph, 1976; 1997). Put simply, placeness is the collection of symbolic meanings and the collective or individual attachment with a spatial setting. According to Lynch (1960), we attribute meaning to landscapes and consequently become attached to the meanings. Establishing 'placeness' is integral to the process of achieving genuine sustainable communities; it is the foundation on which the components essential for sustainability can be set. Without an emotional connection there is no sense of ownership. As a consequence people will feel disinclined to look after property and the parcels of land between buildings and structures (Nassauer, 1997). It is therefore necessary that the marriage of sustainable principles and the notion of place are harmonious.

To begin to make sense of the critical nature of place and the parallels with sustainability it is worthwhile contemplating
Heidegger's perception of place. Heidegger's specific references to architecture, building and dwelling have long informed the attempt to define place within the teaching of design pedagogy. Heidegger is a controversial figure and for some this invalidates his work (Sharr, 2007), but many of his insights in the seminal 'Building, dwelling, thinking' when relating to place also have an identifiable and pertinent connection to sustainability.

'With the banks, the bridge brings to the stream the one and the other expanse of the landscape lying behind them. It brings stream and bank and land into each other's neighbourhood. The bridge gathers the earth as landscape around the stream.'

(Heidegger, 1971)

This refers to the role of a bridge in the transformation of space into place. The place of the bridge's construction is now understood differently because of its being. It is also necessary for the materials used in the construction of the bridge to be local as Heidegger challenged the perception of the earth as a commodity (Sharr, 2007). To Heidegger the ability to dwell is dependent on the individual's need to build or make, this could be in the form of a ritual as banal as setting out the dinner table. Topographic connections between the earth and materials such as clay, wood, steel and sand (materials from the earth) are intrinsic to his notions of dwelling and place. Materials are the tangible substances of place. Space is rearranged into place by the activity of building. The bridge spanning Heidegger's stream is a material construct: without materiality place within the context of the urban landscape does not materialise.

Norberg-Schulz (1976) draws and expands on Heidegger's reasoning and other works such as Husserl's 'The idea of phenomenology' (1936) to develop the notion that people can find meaning in the physical elements of spaces and places. Schulz reasons that the dogmatic and mixed messages of modernism, combined with its universalising nature, are incompatible with creating a unique physical character and the essence of place. In other words, he proposes that designers and architects should 'concretise' the physical characteristics of place by identifying and contextualising notions such as materiality, texture and sensory experience in the design process. These 'concretised' elements are considered as fundamental to creating the character of place. The notion that boundaries define place is open to interpretation. The character of a grouping of buildings representing a place will have conventional recognisable motifs such as doors, windows and roofs: material constructs. When transposed from one place to another the motifs act to bring character and space together, therefore challenging the perception of recognisable boundaries between places. The link between buildings, neighbourhoods, cities and the landscape become more identifiable, connected by the concretised elements of place. 
Materials used for building have traditionally been acquired locally and have consequently created unique regional identities and a sense of place. Utilising local materials is an integral feature of the establishment of the narrative of placeness, but also a benchmark for sustainable practice. The embodied energy cost of local materials is lower than imported alternatives, they are more recognisable and, as a result, help to create a sense of connection to the places they are employed.

Thompson and Sorvig (2008) identify five elemental benchmarks for the application of hard landscaping materials. They are fundamental to the establishment of genuine sustainability, but are also philosophically and contextually associated with the local region

(a) whenever possible specify locally produced products

(b) use less processed materials

(c) produce a rough estimate of energy required to produce and transport materials

(d) explore recycled materials

(e) avoid petroleum-based products.

The application of sustainable landscaping materials, however, is often limited and constrained owing in part to unenlightened attitudes and cost. The absence of authentic local sustainable products and the importation of cheaper quarried products such as Chinese granite raise sustainability issues as well as ethical concerns regarding labour conditions (Weyzig et al., 2008). The use of imported stone frames the dilemma of the aspiration for genuine sustainable material application within urbanity. Tighter regulation has led to increasing costs of local mining/quarrying and production, particularly in Europe and the USA, resulting in economically unviable production and subsequent plant closure. Ninety per cent of dimension stone utilised within the USA is now imported from worldwide locations (Calkins, 2009). As a result, effectively the materiality of place within contemporary developments, has its origins in locations situated hundreds or thousands of miles away. This acts as a fundamental barrier to genuine placebased sustainable design practice, for the most part reflecting the homogenising nature of globalisation, and ensuing dilution of place-based objectives.

\section{Definitions and confusion}

Sustainability is an integral factor in the development and commissioning of architectural and urban landscape projects, but the absence of a clear and agreed definition and the ambivalence of pertinent frameworks often contribute to fuzzy interpretations of the subject (Derbyshire, 2009).

Defining sustainability has become an academic inquiry in itself (Basiago, 2006; Selman, 2008; Toman, 1992 ), correlating this complexity and confusion into its meaning leads to uncertainty. As Walker (2006) emphasises, defining sustainability is not a linear process.

For example, according to Kunszt (2002), an architect would view the efficient utilisation of energy and resources as primary concerns. Smith (2001) also makes the point that the primary aim of the architect 'under the sustainability banner', is to heighten the comfort levels within buildings for their inhabitants. This should occur while simultaneously minimising the reliance on fossil-based energy. By using techniques such as thermal mass, insulation, natural ventilation, and active solar optimisation, energy costs can be significantly lowered.

By contrast, Selman (2008) contends that the landscape may be defined in terms of its economic, social and political sustainability.

(a) Economic: in that the maintenance of visual aesthetics encourages recreation and tourism.

(b) Social: as the role of landscape with its origins in the phenomenological tradition, it is reasoned, encourages inclusivity and participation (Moore-Colyer and Scott, 2005).

(c) Political: as the role of the state and corporate structures in the development of cultural landscapes is intimately connected to production of distinctive landscapes and as such has a wider sustainable impact.

Antrop (2006) proposes that the whole notion of the sustainable landscape is open to contradiction. He suggests that landscapes are continuously evolving 'in more or less a chaotic way' as they reflect social and economic needs. In his view, landscapes have the potential to contribute to sustainability, but are not sustainable in themselves.

The diverse perspectives and complexities of the interpretation of sustainability contribute to a sense of confusion, which is inevitably reflected in the planning and development process of project development. As McGlynn and Murrain (1994) observe, the real power brokers in the development of urban form are the landowners, developers and funding agencies. The influence of architects, designers and planners exists in the substance and conviction of their arguments. Good design can only prevail in parallel with a set of values held by a group or individual; consequently these values need to be understood and effectively communicated.

The need for clarity is acknowledged and analysed in the Egan review (Egan 2004a) into the skills needed to deliver the vision and aims of sustainable communities, facilitating a debate into more effective ways of communication by built environment professions. Generally, the review demonstrates that to turn things around a common goal is needed to deliver better 
Urban Design and Planning

Volume 164 Issue DP1
Sustainable urban habitats:

design intentions to practical

implementation

Derbyshire communities. This requires both the professional skills of architects, planners and designers, but also a set of more generic skills such as governance of communities, communication, risk taking and leadership.

The magnitude of the task in implementing coherent sustainable development practices is highlighted in some of the reactions to the Egan review (Egan, 2004b). In their response to Egan, Inspire East (2006), the regional centre of excellence for sustainable communities, reported 'The word sustainable is used in many different contexts, leading to confusion and lack of thinking between various sector organisations'. This lack of clarity and communication of commonly agreed sustainable practices ultimately contributes to the maintenance of disparate interpretations of the subject and the consequential preservation of the status quo.

\section{Manchester, design and ecology}

The process of design planning of the urban landscape has been described as 'rearranging the deck chairs on the Titanic' (Punter and Carmona, 1997). It is difficult not to subscribe to this reasoning based on the evidence of many of the metropolitan regions of the UK. On the face of it, there appears to be a paucity of creativity and joined up thinking when observing new developments within regional cities. Manchester for example has undergone significant redevelopment over the last decade. In common with other regional cities Manchester has experienced a dramatic increase in the population of the city centre, traditionally occupied by commercial and industrial architecture. The increase in population in the city has risen from approximately 1300 in 1991 to an estimated 20000 in 2010 (Manchester. gov, 2007). Manchester, however, is different: in 1996 an IRA bomb ripped the heart of the commercial centre out with the repair and regeneration bill estimated at $£ 1 \cdot 2$ billion. The redevelopment projects can be viewed as a snapshot of current architectural and urban design thinking and planning as well as the approach to sustainability.

The UK government's planning and sustainable development policy over the last ten years has focused on a mixed-use approach to urban planning ideals (Evans et al., 2009). This is not a new concept. As Zeidler (1985) points out, multi-purpose buildings existed before the industrial revolution and have subsequently been built and used for centuries. Many of the newer developments within Manchester reflect the multi-use interpretation of sustainable development. Multi-functioning commercial developments are now burgeoning phenomena within the city. The self-contained box, combining ground floor retail, leisure and restaurants with upper-floor dwellings and gyms, are a familiar feature. One such example of this type of complex is Spinningfields. This is the newest of the city-centre developments and is also underpinned with residential, leisure, civic and retail spaces (Allied London, 2005). The sustainability of the project is a major trading point and the environmental performance of the buildings are judged to be excellent by the British research establishment environment assessment method (Breeam, 2009).

The architecture of Spinningfields is a combination of the banal and the radical (Derbyshire, 2009), the latter being represented by the civic justice centre (architects, Denton, Corker, Marshal) (Figure 1). This is a multi-award-winning building named as building construction of the year by the Green Construction Awards (Mott MacDonald, 2009).

Given the excellent sustainable credentials of the buildings it is disappointing that conversely the parcels of land between are 'particularly redundant' (Continuity in Architecture, 2009), giving an impression of space left over after planning. The landscaping is humdrum and materials such as imported granite do not measure up to established benchmarks for sustainable practice regarding materials, as referred to earlier (Thompson and Sorvig, 2008).

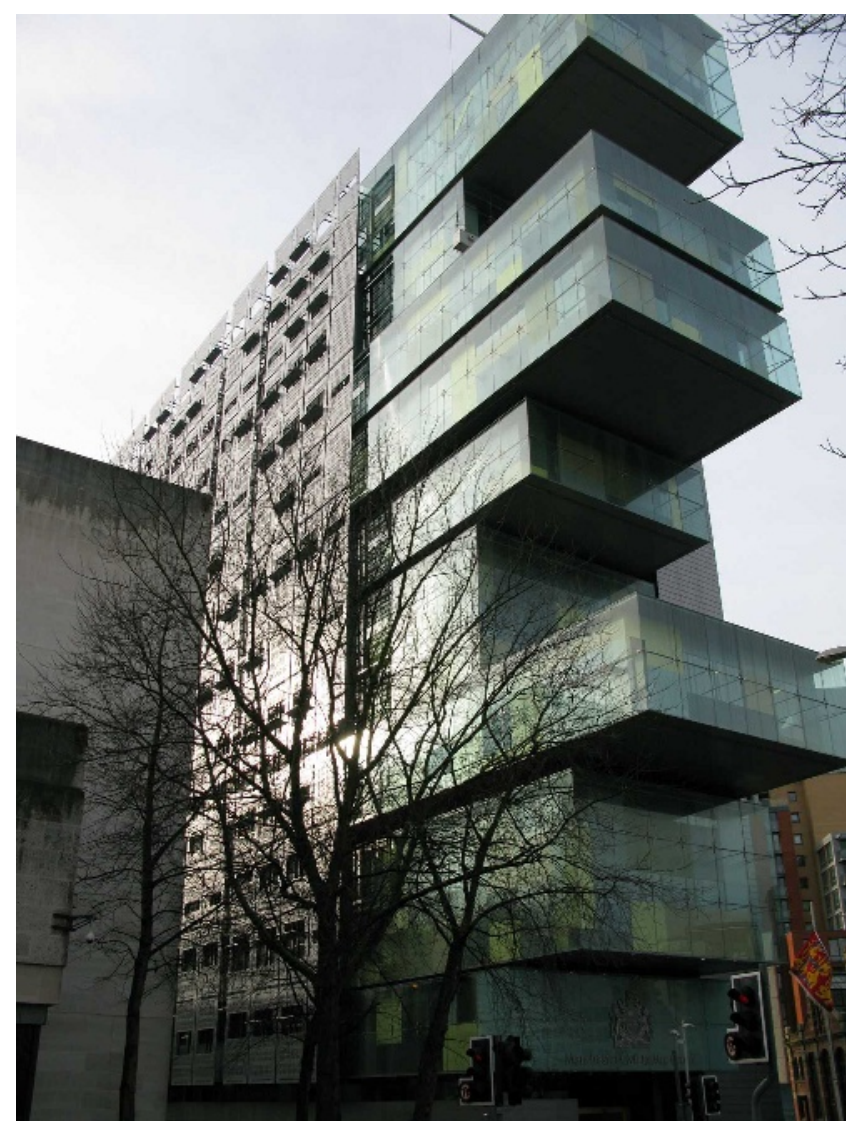

Figure 1. Civic justice centre, Manchester 
Urban Design and Planning

Volume 164 Issue DP1
Sustainable urban habitats:

design intentions to practical

implementation

Derbyshire
Developments such as 'Spinningfields' are indicative of the perception that most landscape designs are replications of one another, the inevitable consequence of which results in humdrum and clichéd designs (Bell, 1999). The public spaces within the development reaffirm this perception. Ecological principles are a secondary consideration and the hard landscaping is used as a method of neutralising the public areas. The developers attempt to create a sense of community and place within the public spaces by employing the use of plazas. However, the plazas here appear to be more corporate in derivation rather than an attempt to create an urban oasis. This is unfortunate given the potential role of local ecological diversity in engendering placeness. According to Hough (1990), the connection with local ecological values and principles is a marker to establishing a sense of place. Consequently, an opportunity has been missed: the Spinningfields development instead reflects the disparity between architecture and the landscape, appearing to 'ignore the landscape except as a backdrop to the grand architectural statement' (Osmond, 2002). If the use of plant materials within urban space is ever to be more than a perfunctory nod in the direction of environmentalism, a more inspired 'concretisation' of regional nature should be regarded as a foundational component of urbanity.

The manner in which ecology is applied has been a vexed issue among design professionals, particularly the role of science and natural processes as an alternative source of inspiration to 'traditional' methods. The notion that science can be the principal source for the design of landscapes was regarded as a radical innovation in the 1960s and 1970s, but is now viewed as a model for the sustainable landscape. This in part is owing to the rise in the recognition of environmentalism and global ecological awareness, but also the growing realisation that the landscape can be a source of establishing unique regional identities. As Corner (2006) observes, the notion of the ecology of the city and the cultural, social and economic consequences of this symmetrical existence are still to be fully researched and understood. Integrating landscape ecology principles within the urban landscape, that is combining urban morphology with ecological functioning, is not a straightforward undertaking. Accordingly, Ahern (2005) notes that assimilating ecological principles with architecture, planning and design in order to achieve urban sustainability is still in the early stages and as many challenges as opportunities are expected.

Much of the current debate surrounding the aesthetics of ecological design implementation centres on the need to compromise the beauty of a given design in favour of projects that are 'environmentally responsible but a little ugly' (Griswold, 1994). Given the subjectivity of the concepts of 'ugly' and 'beautiful' this dialogue raises pertinent issues regarding the relationship between natural processes and design practice; does one preclude the other? Cook (2000) reasons that a dynamic change has emerged in the underlying assumptions supporting an understanding of the natural world. He contends that a greater understanding of ecology aids the designer as design projects usually involve intervention and rearrangement of the land. A biological understanding of the consequences would help and predict the control and outcome of the intervention. In other words the designer is able to identify an aesthetic that will have minimal impact on the ecological function of the site. Additionally, the narrative of the ecology and feelings provoked by an ecological perspective, could serve as an aesthetic and therefore inspirational challenge to the design process.

The Spinningfields case study, by contrast, is an example of traditional modernist and post-modern design rationale. Whereas modernism responded to the challenge of creating social order in mass societies through functionality and structure, its focus on the architectural object, rather than the requirements of the site (Ellin, 1996), runs counter to notions of ecological integration. Conversely, post-modernism sought to address the wider needs other than the rigid adherence to form and function. Generally, there was an attempt to address the relationship between human experience and architecture, a regard for architecture within the context of society (Huxtable, 1981). Whereas the architecture in Spinningfields refers to both modernist and post-modern sensibilities, the public spaces 'speak' more of the traditions of utilitarian modernism.

The sustainability of the architecture also contrasts sharply with the standard design solutions of the spaces between. Trees are planted in regimented rows and the grassed foliage (in a box) areas are uninspiring and uninviting (Figure 2). The beauty of the development is open to interpretation, but the

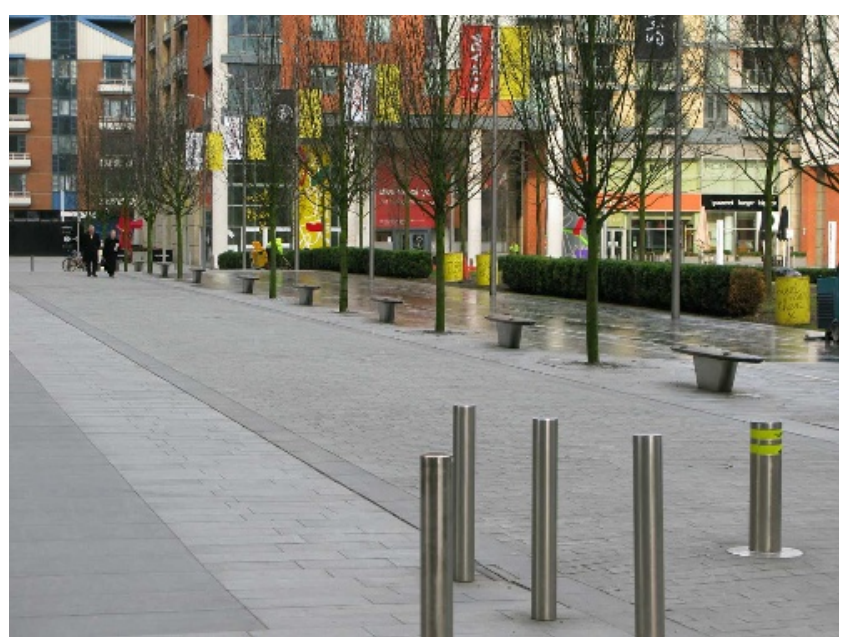

Figure 2. Civic justice centre, Manchester 
Urban Design and Planning

Volume 164 Issue DP1
Sustainable urban habitats:

design intentions to practical

implementation

Derbyshire sustainable and ecological aspirations are not. The timehonoured design methods represented here fail to establish ownership, place or connection with the local community in any meaningful manner with seemingly no encouragement to engender 'placeness' through shared ownership of the spaces. However, there are alternative design solutions to consider. Hough (1995) argues against 'the fixed mould of aesthetic convention'. He reasons that the designed pedigreed landscapes of mown turf, flowerbeds and fountains and so on are dependent on 'high energy inputs and horticultural technology'. His reasoning for a more ecologically diverse 'fortuitous landscape' such as urban weeds is persuasive; the task of linking nature with urbanism, the synthesis of ecology and materials is elemental to sustainable viability and also makes sense in terms of the habitability of urbanity. For example, roadside plants help reduce carbon monoxide levels and wallclimbing plants can reduce summer temperatures on a street by 5\% (Hough, 1984). Ecological diversity is an integral part of the health and quality of urban life. The associated negative perception of the aesthetics of ecological design has maintained a 'play it safe' approach to the sustainable development of metropolitan centres maintaining the status quo.

'Ecological design needs to teach and convey with greater emphasis the possibility: indeed historically the fact, that the dynamic interaction between humans and the ecological world can be positive and mutually beneficial.'

(Mozingo, 1997)

The shift in the way the built environment professions perceive the urban landscape: that is, moving from the actual reality of 'ecology in cities' to the notional 'ecology of cities', is fundamental to the establishment of a more sustainable ecological urban form. As such Berger (2006) argues that a more progressive approach to ecological urbanity can be formulated through existing knowledge structures, such as rethinking the nature of place in small patches of urban space within what he describes as 'drosscape'. Berger attaches no value system to these post-industrial spaces; they are neither bad nor good, but in need of new conceptualisation. In reality, however, despite countless perspectives on environmental issues being expressed, for most part professional landscape design practice does not support the rhetoric (Nadenick and Hastings, 2000). The challenge for the urban design professions is to channel existing knowledge structures to create a radical renegotiation of placeness and subsequent sustainability of urban spaces.

\section{Green roofs and living walls}

The existence of green roofs and living walls can be viewed as a progressive and imaginative means of breathing life into the city. They provide a further step in the direction of a more nature inspired perception of urbanity, and are a viable alternative in establishing a more nature-inspired, place-based model for design. Nevertheless, where and how they are deployed can either be a positive contribution to a more nature-inspired urbanity, or reflect clichéd design outcomes. Generally, they are roofs that bear vegetation. They can either be designed and included within new architectural projects or included on and within existing structures. The constituent elements of green roofs will vary depending on the client's needs, but ordinarily they comprise a substrate material usually composed of local non-organic materials acting as a drainage medium. This underpins and supports an organic growing medium, which in turn supports the plant materials, typically sedum mixtures, herbaceous materials and grasses. There are many advantages to specifying the utilisation of grass roofs within structures. There are the obvious ecological benefits, such as (Johnston and Newton, 1988)

(a) reduction of storm water run off

(b) provision of wildlife habitats

(c) absorption of carbon dioxide, some air pollutants and dust

(d) links in citywide networks of greenspace

(e) reduction of urban 'heat island' effect.

But also sound financial and technical reasons, such as lower maintenance costs and increased thermal and acoustic insulation. The benefits of what are also described as eco-roofs, living roofs and brown roofs are increasingly being acknowledged and incorporated within new and refitted structures. For instance, London has installed $230000 \mathrm{~m}^{2}$ in the last four years (Martin, 2009), and Chicago now has approximately 278000 square meters of green roof space (Cantor, 2008).

Although green roofs are a valuable additional feature to a more nature-inspired urbanity, when in view and accessible to the public, the adoption of the traditional practice of pedigreed, high-maintenance applications of plant materials is a familiar design default. As such, the Scottish parliament building in Edinburgh (Figure 3) is representative of a more intensive green roof design. This roof trades on conventional aesthetics; the primary objective is to create a similar environment to parkland or a designed garden. This is in stark contrast to the Barclays building in Canary Wharf London (Figure 4). This is a bio-diverse roof, designed to replicate the local ecological environmental character of the site and create a natural habitat to support a variety of flora and fauna. However, this roof is not accessible to the public or occupants of the building and consequently the potential to establish a connection to, or a sense of ownership of this unconventional but valuable urban landscape feature is lost.

Living walls are a correlation to green roofs, the vertical application of green roof processes. As such, the Consorcio building in Santiago, Chile (Figure 5) is one of the most 
Sustainable urban habitats:

design intentions to practical

implementation

Derbyshire

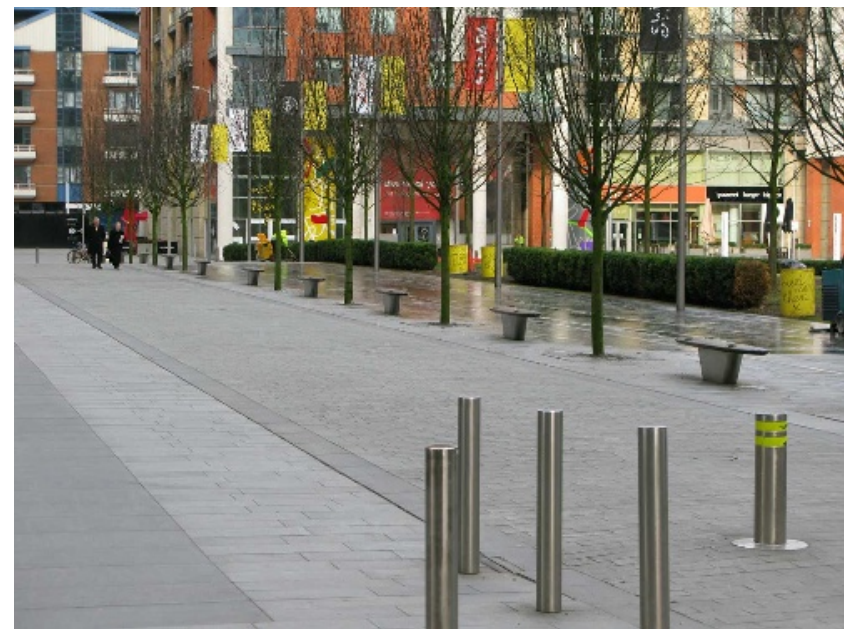

Figure 3. Scottish parliament building, Edinburgh

recognisable examples. The living wall's principal benefit when compared with green roofs is its visibility. There are two conventional types of green wall systems: façade greening and living walls. For most part living walls are part of a building envelope system, in that plants are grown within a modular walls system. Green façades are generally trellis or training structures that support vertically growing plants that are not attached to the building. Living walls can improve indoor air quality by removing toxic chemicals and carbon dioxide and can insulate against summer heat and winter cold (Cantor, 2008).

Living walls are a visible reference to living architecture and the ecology of place, connecting urban dwellers with nature. Although construction materials and installation techniques are similar regardless of location, different climates and economies can determine local substrate materials and plant materials. The use of local materials and ecologies affords the architect and designer the opportunity to create corresponding

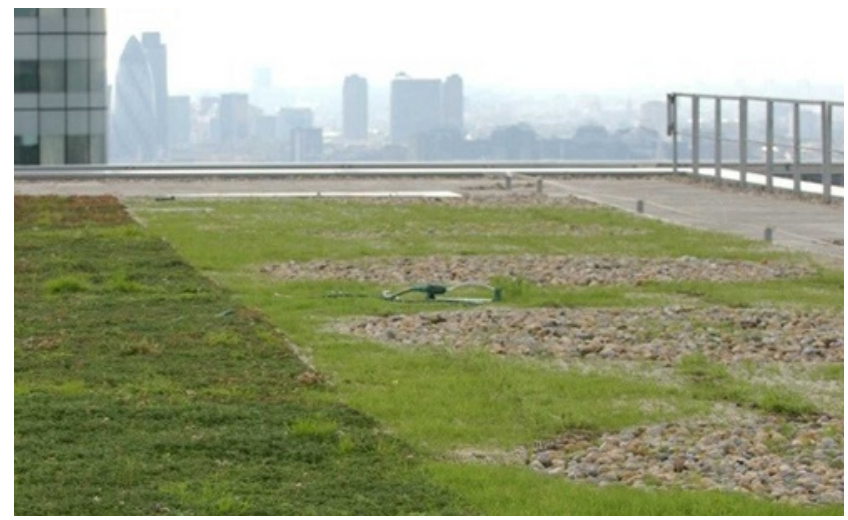

Figure 4. Barclays building, Canary Wharf, London

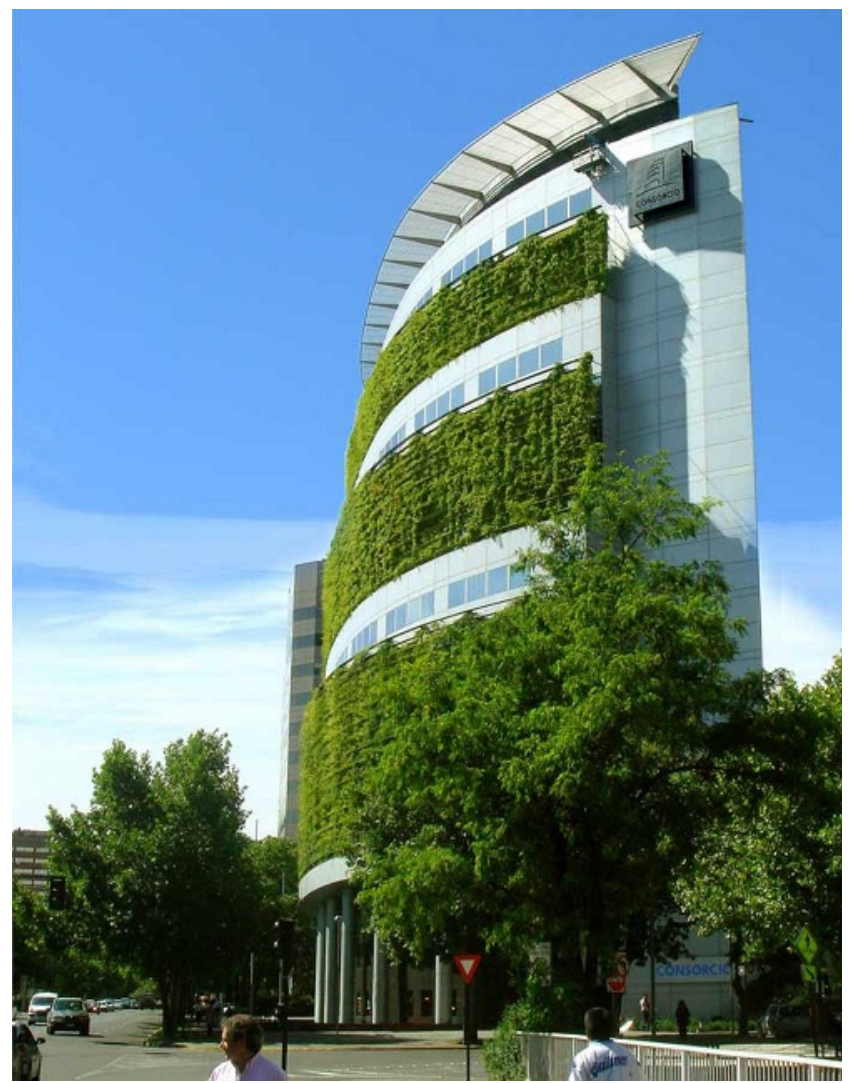

Figure 5. Consorcio building in Santiago, Chile

regionally distinct living architecture and an alternative urban landscape form.

The greening of buildings through the use of green roofs and walls is a genuine marker of the progress made to more pleasant and environmentally intelligent urbanity. They are also a good investment in terms of their cost benefits, both in terms of their economic pay off, and for the well-being of their inhabitants. Green roof installation can reduce the cost of drainage and, by using local recycled aggregates, can reduce the cost of roof construction, as well as offering significant fuel/heating savings (Gedge and Frith, 2004). Their use can also assist local green industries, creating a potential niche market for nurseries growing ground covers, grasses or perennials. Additionally, it has been proposed that increasing visible green space promotes health by relieving mental fatigue (Kaplan, 2001), therefore contributing to a more habitable living and working environment within the building and, when visible, providing similar psychological benefits to neighbouring inhabitants.

Green roofs and living walls are genuinely valuable additions to the ecological landscape. The demarcation between ground 
Urban Design and Planning

Volume 164 Issue DP1
Sustainable urban habitats:

design intentions to practical

implementation

Derbyshire and roof surface is becoming more ambiguous as we view the landscape through tools such as a Google Earth (Thompson and Sorvig, 2008). The potential to create progressive ecologically inspired landscapes already exists within the city, but is unlikely to challenge 'fixed mould' design orthodoxies if no one sees them. Green roofs and living walls provide an option for a more holistic, multi-disciplinary and regionally variable move towards the notion of living architecture, a more sustainable urban form.

\section{Conclusion}

The task of creating ecologically diverse urbanity and creative sustainable metropolitan centres is an intricate undertaking, made more complicated by the apparent resistance to adopt sustainable and ecological principles by design professionals. This resistance has more to do with unfamiliarity or misunderstanding of concepts of place and sustainability. This inevitably stems from inconsistent sustainable design methodologies and training. Concepts of place are difficult to define and interpret, and the nature of sustainability is open to interpretation depending on its context, which inevitably leads to inconsistent approaches to genuinely sustainable practices. The pattern of inconsistency can be observed in the landscape of urban spaces; the sense of place appears to be an arbitrary concept, materials are imported and the choice of ecology conforms to traditional design choices and rationale. Ostensibly architects appear to have a clear and structured set of sustainable principles and guidelines to refer to (Riba, 2003), contrasting with the designed spaces between, which rely on traditional modernist theory as the primary source of inspiration. The overall result is a landscape that gives the impression of relying on 'safe' design implementation and no more than a superficial reference to sustainable practice.

International modernism still has a secure part to play in the development of the landscape. Given the cultural complexities of the urban landscape people will always identify with other places. Modernism represents a connection to the familiar, but the increase in city-centre living and the re-negotiation of postindustrial/commercial centres requires a more proactive approach to sustainable design. A more ecological-based approach to the design process has suffered from the tag of ethic rather than a fully conceived aesthetic (Mozingo, 1997). This perception remains despite persuasive grounds for the reevaluation of conventional design outcomes. The use of natural processes and ecology within design processes should be viewed as a creative addition to the objective of genuinely sustainable landscape design. The failure to embrace the notional shift necessary in viewing the landscape as a potential model for a more regionally distinctive urban form is at the heart of the matter. It speaks of a failure of imagination, but also of a lack of understanding of the inter-relationship between the role of ecology, place, design and sustainability.
Green roofs and living walls are a tangible step in the right direction and as such are a recognisable benchmark for a more ecological, place-based response to the aspiration of sustainable urbanity. Their increase in popularity is indicative of environmental legislation, but also the developer's awareness of the marketable appeal of greener, more sustainable, urban developments. The acknowledgement of the role of ecology/ green roofs within architecture as a contributor to emotional well-being is a welcome move in the right direction, but more needs to be done.

The goal of achieving a more sustainable urban landscape form can be viewed as resolving a complex equation. Creativity can be seen as one of the variables providing a solution, but there are more fundamental concerns that need to be addressed if this is ever to become a reality, such as

(a) viewing place and sustainability as two sides of the same coin

(b) regarding ecological design as positive addition to design rationale

(c) viewing sustainable design as a fundamental to the design process on a par with the development of form and space.

The vagaries of the concepts of sustainability and place have in part contributed to a piecemeal adoption of genuine sustainable practices, but it is this ambiguity that invites an imaginative response to the sustainable design of the urban landscape. Theories of place are fundamental to the urban design process. The connection with sustainability is organic. Without dwelling, ownership and emotional responses sustainability does not exist.

The Manchester case study is a reminder of the distance that still needs to be travelled in order to begin to realise genuine sustainable urbanity. It acts as a prompt for the need to change direction, a transparent perspective for conventional thinking. The challenge facing the built environment professions is to substitute rhetoric with practical actions.

\section{REFERENCES}

Ahern J (2005) Integration of landscape ecology and landscape architecture: an evolutionary and reciprocal process. In, Issues and Perspectives in Landscape Ecology (Wiens JA (ed.)). Cambridge University Press, Cambridge.

Allied London (2005) Spinningfields. See http://www. spinningfieldsonline.com (accessed 07/01/2009).

Antrop M (2006) Sustainable landscapes: contradiction, fiction or utopia? Landscape and Urban Planning 75(3-4): 187-197.

Basiago A (2006) Methods of defining 'sustainability. Sustainable Development 3(3): 109-119.

Bell S (1999) Landscape Pattern Perception and Process. Routledge, London. 
Berger A (2006) Drosscape. Princeton Architectural Press, New York.

Brandenburgh AM and Carroll MS (1995) Your place or mine? The effect of place creation on environmental values and landscape meanings. Society and Natural Resources 8(5): 381-398.

Breeam (Building Research Establishment Environmental Assessment Method) (2009) The code for sustainable homes. See http://www.breeam.org/ (accessed on 06/01/2009).

Calkins M (2009) Materials for Sustainable Sites: A Complete Guide to the Evaluation, Selection, and Use of Sustainable Construction Materials. John Wiley, New York.

Cantor SL (2008) Green Roofs in Sustainable Landscape Design. W.W. Norton \& Company, London.

Continuity in Architecture (2009) By John Rylands Library I sat down and wept... See http://www.msa.mmu.ac.uk/ continuity/index.php/2009/01/15/by-john-rylands-library-isat-down-and-wept.../. (accessed 02/02/2009).

Cook R (2000) Do landscapes learn? Ecology's 'new paradigm' and design in landscape architecture. In Environmentalism in Landscape Architecture (Conan M (ed.)). Dumbarton Oaks, Washington DC.

Corner J (2006) Terra fluxus. In The Landscape Urban Reader (Waldheim C (ed.)). Princeton Architectural Press, New York.

Derbyshire A (2009) Modular sustainability within the landscape. Design Principles and Practice an International Journal 3(2): 227-247.

Egan J (2004a) The Egan Review, Skills for Sustainable Communities. The Office of the Deputy Prime Minister, London.

Egan J (2004b) The Egan review responses. See http://www. communities.gov.uk/archived/publications/communities/ eganreview (accessed 02/01/2009).

Ellin N (1996) Postmodern Urbanism. Princeton Architectural Press, New York.

Evans G, Aiesha R and Foord J (2009) Designing Sustainable Cities, Urban Sustainability: Mixed Use or Mixed Messages? Wiley-Blackwell, London.

Gedge D and Frith M (2004) Green Roofs Benefits and Cost Implications. Birmingham City Council.

Griswold M (1994) The year of living responsibly. Landscape Architecture 84(11): 52-55.

Heidegger M (1971) Poetry Language Thought. Harper Colophon Books, New York.

Hester RT (1995) Life, liberty and the pursuit of sustainable happiness. Places 9(2): 4-17.

Hough M (1984) City Form and Natural Process. Croom Helm, London.

Hough M (1990) Principles for Regional Design, from Out of Place: Restoring Identity to the Regional Landscape. Yale University Press, New Haven, CT.
Hough M (1995) Cities and Natural Process: A Basis for Sustainability. Taylor \& Francis, New York.

Husserl E (1936) The Crisis of European Sciences and Transcendental Phenomenology. Northwestern University Press, Evanston, IL.

Huxtable AL (1981) The troubled state of modern architecture. Architectural Record 169: 72-79.

Inspire East (2006) Summary of the Skills for Sustainable EX Communities Report: An Investigation of Skills Gaps among those Tasked with Delivering Sustainable Communities in the East Region. See http://www.inspire-east.org.uk/fileaccess. aspx?id=968 (accessed 12/03/2009).

Johnston J and Newton J (1988) Building green: a guide to using plants on roofs. In Walls and Pavements. London Ecology Unit, London.

Kaplan S (2001) Meditation, restoration and the management of mental fatigue. Environment and Behaviour 33(4): 480-506.

Kunszt G (2002) Sustainable architecture. Periodica Polytechnica Series Civil Engineering 47(1): 5-10.

Lynch K (1960) The Image of the City. MIT Press, Cambridge. Manchester.gov (2007) Manchester City Centre Population Estimate Planning Area. See http://www.manchester.gov. uk/downloads/A15_CityCentrePopEst_Oct07_1_.pdf (accessed 04/01/2009).

Martin G (2009) New York's hanging gardens. The Observer Magazine, 8th November 2009, p. 38.

McGlynn S and Murrain P (1994) The politics of urban design. Planning Practice and Research 9(3): 311-320.

Moore-Colyer R and Scott A (2005) What kind of landscape do we want? Past, present and future perspectives. Landscape Research 30(4): 501-523.

Motloch J (2001) Introduction to Landscape Design. Van Nostrand Reinhold. New York.

Mott MacDonald (2009) Manchester Civil Justice Centre. See http://www.mottmac.com/projects/?id=30075\#top (accessed 06/01/2009).

Mozingo L (1997) The aesthetics of ecological design: seeing science as culture. Landscape Journal 16(1): 46-59.

Nadenicek J and Hastings C (2000) Environmental rhetoric, environmental sophism: the words and work of landscape architecture. Proceedings of Dumbarton Oaks Colloquium on the History of Landscape Architecture 22. Harvard University, Washington DC.

Nassauer Jl (1997) Placing Nature, Culture and Landscape Ecology. Island Press, Washington DC.

Norberg-Schulz C (1976) The phenomenon of place. Architectural Association Quarterly 8(4): 3-10.

Osmond P (2002) The sustainable landscape. In Design for Sustainability (Birkeland J (ed.)). Earthscan, London.

Punter J and Carmona M (1997) The Design Dimension of Planning: Theory, Content, and Best Practice for Design Policies. Taylor \& Francis, New York.

Relph E (1976) Place and Placelessness. Pion Limited, London. 
Relph E (1997) Sense of place. In Ten Geographic Ideas that Changed the World (Hanson S (ed.)). Rutgers University Press, New Brunswich, NJ.

RIBA (Royal Institute of British Architecture) (2003) Sustainable Communities: RIBA Response to the Egan Review of Skills in the Built Environment Professions. RIBA, London.

Selman P (2008) What do we mean by sustainable landscape? Sustainability: Science, Practice and Policy. See http://sspp. proquest.com/archives/vol4iss2/communityessay.selman. html (accessed 17/04/2009).

Sharr A (2007) Heidegger for Architects. Routledge, London. Smith PF (2001) Architecture in a Climate of Change. Elsevier, London.
Thompson JW and Sorvig K (2008) Sustainable Landscape Construction: A Guide to Green Building Outdoors, 2 edn. Island Press, London.

Toman MA (1992) The difficulty in defining sustainability.

Resources for the Future. See http://users.uom.gr/ esartz/ teaching/genvecon/adiffin.pdf (accessed 11/02/2010).

Walker S (2006) Sustainable by Design. Earthscan, London. Weyzig F, Bjurling K and Wong S (2008) Improving Working Conditions at Chinese Natural Stone Companies. See http:// www.indianet.nl/pdf/rap-swedwatch-somo.pdf (accessed 22/02/2009).

Zeidler EH (1985) Multi Use Architecture in the Urban Context. Van Nostrand Reinhold, New York.

\section{WHAT DO YOU THINK?}

To discuss this paper, please email up to 500 words to the editor at journals@ice.org.uk. Your contribution will be forwarded to the author(s) for a reply and, if considered appropriate by the editorial panel, will be published as discussion in a future issue of the journal.

Proceedings journals rely entirely on contributions sent in by civil engineering professionals, academics and students. Papers should be 2000-5000 words long (briefing papers should be 1000-2000 words long), with adequate illustrations and references. You can submit your paper online via www.icevirtuallibrary.com/content/journals, where you will also find detailed author guidelines. 